\title{
The child-nature-time relationship-New challenges for special education in the 21st century - study report
}

\begin{abstract}
Joanna Godawa, The child-nature-time relationship-New challenges for special education in the 21st century - study report. Interdisciplinary Contexts of Special Pedagogy, no. 27, Poznań 2019. Pp. 83-98. Adam Mickiewicz University Press. ISSN 2300-391X. e-ISSN 2658-283X. DOI: https:/ / doi.org/10.14746/ikps.2019.27.04

The objective of the article is to show an individual's relationship with nature in the context of the nature deficit disorder. In light of the limited volume of Polish studies concerning children and nature, the author had conducted a study concerning the relationship between children with special education needs and nature. The research shown in this article is part of a broader study conducted by the author of the article and concerning the nature deficit disorder.
\end{abstract}

KEY WORDS: nature, child, time, nature deficit disorder, sustainable development, special education

"Undergrowth, shrubbery, meadows, and rushes...
everything I say to you is a monologue,
and it is not you who's listening.
A conversation with you is necessary and impossible,
urgent in a hurried life
and postponed for never".
Wistawa Szymborska ${ }^{1}$

1 W. Szymborska, The Silence of Plants, transl. by Joanna Trzeciak <https:/ / www. poetrynook.com/poem/silence-plants>. 


\section{Introduction}

The concept of "nature" stems from the Latin word nasce, which means that which has grown, which has emerged of itself, without human intervention, what was left to develop on its own. ${ }^{2}$ "In its broader meaning, nature encompasses the material world along with all its objects and phenomena [...] in another meaning, nature is open space, according to this concept, the construct of man does not form a part of nature and is distinct from it" ${ }^{3}$ In recent years, a reconfiguration took place of the relationship that exists between man and nature, through the discourse on sustainable growth, which was defined as one that corresponds to the present needs of man without the need to limit the capacities of future generations to satisfy their needs. 193 member states of the United Nations Organisation have achieved an agreement on the objectives and tasks of sustainable development, which founds its reflection in the document: "Transforming our World: the 2030 Agenda for Sustainable Development". Development requires joint effort in the establishment of a future that is sustainable and resistant to catastrophes for all people in the world and for our planet. In order to achieve sustainable development, the congruence of three key components is required: economic growth, social inclusion, environmental protection. ${ }^{4}$

In the opinion of Ewa Szadzińska, the ecological aspect of sustainable development currently dominates formal environmental/ ecological education in Poland. Within informal education in turn, it is primarily the social aspect of sustainable growth that attracts the most attention; it is referred to as global education [...] Contempo-

2 E. Włodarczyk, Kultura, [in:] Encyklopedia Pedagogiczna XXI wieku. vol. 2, G-Ł. ed. by E. Adamczuk, Wydawnictwo Akademickie „Żak”, Warszawa 2003, p. 950.

${ }^{3}$ R. Louv, Ostanie dziecko lasu. Jak uchronić dzieci przed zespotem deficytu natury, Mamania, Grupa wydawnicza Relacja, Warszawa 2008, p. 22.

$4<$ http://www.unic.un.org.pl/strony-2011-2015/zrownowazony-rozwoj-i-celezrownowazonego-rozwoju/2860> [30.05.2019]. 
raneously, people engaged in solving ecological, economic and social problems refer to the idea of sustainable growth. ${ }^{5}$

According to Richard Louv, contemporary people spend less and less time surrounded by nature. According to studies from the United States, children spend less and less time playing outside and playing freely [...] Jane Clark refers to contemporary children as "containerised kids" - as in their opinion, entire generations of children are not only grown at home, but also within an ever smaller space. Children spend more and more time "in car seats, in high chairs or even in special chairs for watching television [...] the chasm between childhood and nature is only a part of a greater dysfunction - the physical limitation of childhood in an urbanised world". ${ }^{6}$

A dispute has been going on for a long time whether time and space are absolute entities with their own nature, or whether they are derivative entities. Time limits human activity more strictly than money, as it passes inevitably and subordinates everyone to its passing: neither people nor animals or any other organisms may escape the passage of time. ${ }^{7}$ The need of time - free, unordered time to dream - to experience nature in a deeper way. ${ }^{8}$

The deep bond with nature is established mainly on the basis of direct, multi-sensual experiences, from time spent in the courtyard or just the yard, to weekends spent in the park and on occasional trips to nowhere. The deep understanding of nature must take place multi-sensually [...] However, we primarily have to encourage people to spend time in the natural environment. ${ }^{9}$

${ }^{5}$ E. Szadzińska, Zrównoważony rozwój inspiracją dla zmian w edukacji wczesnoszkolnej, „Lubelski Rocznik Pedagogiczny” 2017, vol. XXXVI, issue 1, p. 30.

${ }^{6}$ R. Louv, Ostanie dziecko lasu. Jak uchronić dzieci przed zespołem deficytu natury, Mamania, Grupa wydawnicza Relacja, Warszawa 2008, pp. 52-54.

7 P. Macnaghten, J. Urry, Alternatywne Przyrody. Nowe myślenie o przyrodzie i społeczeństwie, Wydawnictwo Naukowe SCHOLAR, Warszawa 2005, pp. 184-191.

${ }^{8}$ R. Louv, Ostanie dziecko lasu. Jak uchronić dzieci przed zespołem deficytu natury, Mamania, Grupa wydawnicza Relacja, Warszawa 2008, p. 148.

9 D. Scott Sampson, Kalosze petne kijanek. Jak dzięki rozwijaniu miłości do przyrody wychować kreatywne, odważne i odpowiedzialne dziecko, Wydawnictwo Vivante, Białystok 2016, pp. 79-80. 
Werner Michl, author of the model of learning by experiment, developed descriptions of relations between activity and cognition and the transfer of what was learned into everyday life. Within the context of getting to know the world of nature and spreading the idea of returning to nature, this model seems to be very interesting. Its roots reach back to the paedagogy of experiences, which based on the holistic approach, describes its goal as enabling the individual to learn directly on the basis of new experiences, while engaging the emotional, intellectual sphere, and through practical activity. ${ }^{10}$

Werner Michl notes that the process of acquisition of new experiences should take place under the guidance of a mentor or best a companion, and be composed of the following parts:

- Event (activity, action, undertaking, taking place in the natural environment; the activity can be planned as well as spontaneous; the situation that the participants of the event are faced with should constitute an opportunity at discovery of new areas of one's capacities.

- Event experience (supposed to evoke engagement, cause emotions, self-reflection, personal experiences).

- Personal experience (mode of expression of one's own opinion, statement and sharing personal experiences with others).

- Cognition (knowledge gained in this way is subjected to objectivisation, ordered knowledge should be transferable to the everyday life of the person making the experience).

- Werner Michl stresses that a balance should be maintained between events, event experiences, personal experiences and cognition. ${ }^{11}$

$R$. Louv was the first to formulate the concept of the Nature deficit disorder, which "describes the price that humanity pays for turning away from nature: reduced use of senses, attention deficit,

${ }^{10}$ M. Meyer, Pedagogika przeżywania, [in:] Adamczuk E. (ed.), Encyklopedia Pedagogiczna XXI wieku, vol. 4, Wydawnictwo Akademickie "Żak”, Warszawa 2003, pp. 239-242.

11 R. Ryszka, Pedagogika przeżyć praktycznie. O nowej metodzie pracy grupowej, Oficyna Wydawnicza „Impuls”, Kraków 2016, pp. 63-65. 
more frequent physical and mental diseases [...] the deficit of nature can change human behaviour in cities, but also the way cities are planned out" ${ }^{12}$ Contact with nature is a need of the 21st century individual in order for them to find a balance between modern technology and that which is natural and our cultural heritage. The establishment of pro-environment attitudes in children and adults also necessitates this special bond with nature that will make us feel responsible for the fate and condition of the world around us. Every contact of a child with animals, plants, with components of inanimate nature $[. .$.$] is a meeting with its environment of life. Children$ grow into it, learn its laws and phenomena. [...] By its nature, the child is a keen observer, a diligent researcher, and their learning takes on diverse forms, both of spontaneous searches as well as systemic work under the guidance of a parent or teacher. ${ }^{13}$

\section{Own research methodology}

The main objective of the presented research was to check, what are the properties of the contact of children with special education needs with the world of nature in the context of free play in the open, in natural space, according to the concept of S.D. Sampson on the establishment of a deep bond with nature on the basis of direct, multi-sensual experiences that arise in the time spent in the yard, the park and in other green areas. Significantly important components of research are also the availability of green spaces, the distance between the place of residence and playgrounds, parental fears related to the child remaining outdoors as well as outside activities that families prefer in the weekends. Empirical material for the analysis was acquired during survey evaluations via a questionnaire. The study was conducted in the year 2019 in the second

12 R. Louv, Ostanie dziecko lasu. Jak uchronić dzieci przed zespołem deficytu natury, Mamania, Grupa wydawnicza Relacja, Warszawa 2008, p. 54.

${ }^{13}$ A. Budniak, Edukacja społeczno-przyrodnicza dzieci w wieku przedszkolnym i młodszym wieku szkolnym, Oficyna Wydawnicza „Impuls”, Kraków 2012, p. 162. 
half of April, in the Silesian voivodeship of Poland, which is characterised by a high level of urbanisation and the fifth rank among all voivodeships in Poland by forest area (403.8 thousand hectares). ${ }^{14}$

The study was responded to by mothers at $100 \%$, even though this was not the objective of the author, and the surveys were aimed at both parents.

The study saw the participation of 110 parents of children with special education needs, with the exclusion of children with motor system dysfunctions and deep intellectual disability (it was important for the purpose of the study for the children to be able to freely move about and, to the greatest possible extent, spend time independently playing freely in natural space). $53 \%$ of the children concerned by the study attended preschool, $18.8 \%$ attended primary school - forms I-III, 21\% attended forms VI-IV of primary school and $6.2 \%$ attended forms VII-VIII of primary school.

The surveyed persons reside in the following types of localities: towns of up to 20,000 inhabitants $-39.4 \%$, towns up to 100,000 inhabitants $-12.1 \%$, cities above 100,000 inhabitants $-30.3 \%$, rural areas $-18.2 \%$.

An analysis was conducted of the distance between the place of residence of the surveyed parents and the nearest playground. The most numerous group of parents surveyed, $34 \%$, indicated that the next playground is ten minutes away from home, $25 \%$ parents had their closest playground five minutes away from home, and 18.8\% can see the playground from the window, $21 \%$ of the surveyed does not have a playground near their place of residence.

The distance between the place of residence of the surveyed persons to the forest breaks down as follows: five-minute walk $-34.4 \%$, ten-minute walk $-21.9 \%$, up to a 30 -minute drive $-18.8 \%$, a $15-20-$ minute walk $-15.6 \%$, only $9.4 \%$ of those surveyed stated that the forest is far away from the locality they live in. The group was chosen

14 Data from a publication by Statistics Poland and the Department of Agriculture: Forestry 2015. Information and statistical study, also available under <stat.gov.pl> [19.08.2019]. 
purposefully, with the criterion being having a son or daughter with special education needs. The research presented in the article was conducted according to the quantitative research paradigm.

\section{Study results}

Diagram no. 1 shows test results, with the objective being to show the total time the children spend outside, paying freely after the time spent at school or at preschool, during learning weekdays. As the diagram shows, the most of those surveyed selected the response of one hour, $31.3 \%$ of those surveyed. The second most popular response given by the parents was the statement that the children spend two hours a week outside - $25 \% .15 .6 \%$ of children spend 30 minutes outside, with $15.5 \%$ of children going outside during school days for less than 30 minutes. The least children spend three hours and more outside - only $12.5 \%$.

Diagram no. 1

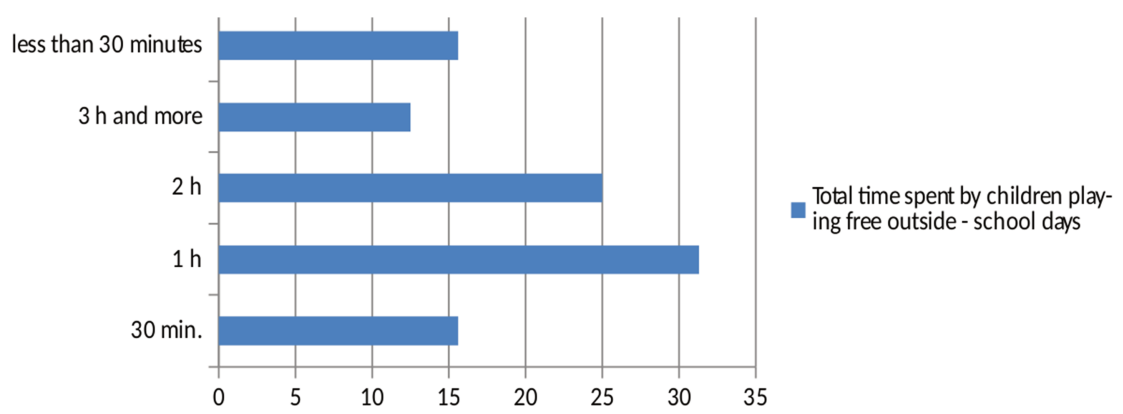

Source: Own research.

Diagram no. 2 shows the total time spend by the children outside in weekends, during free play in the open. The majority of persons among the surveyed parents responded by saying: three hours or more - at $65.6 \%$, the second most popular answer was two hours, as 
given by $15.6 \%$ of respondents, $9.4 \%$ of children spend one hour outside in the weekends, $6.3 \%$ of children spend 30 minutes playing outside and just $3.1 \%$ spend less than 30 minutes outside, playing freely.

\section{Diagram no. 2}

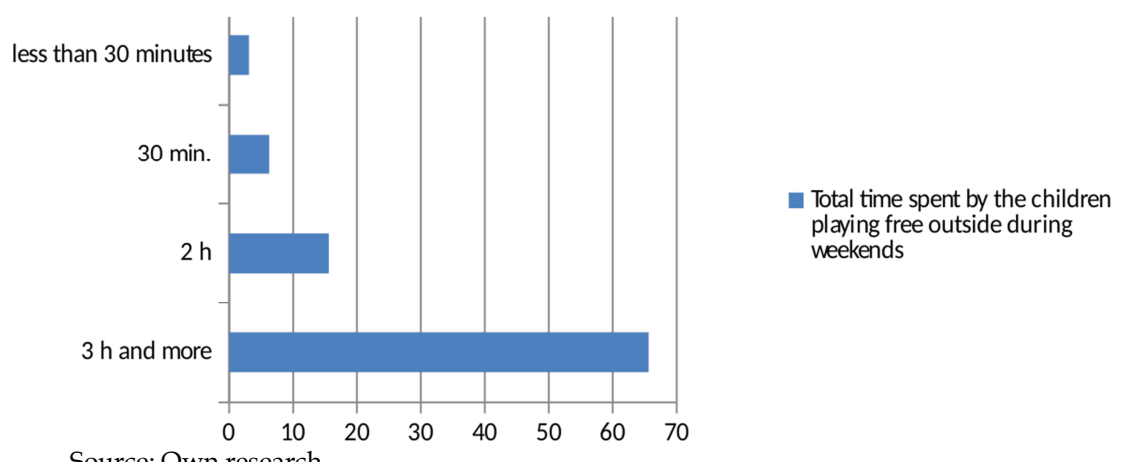

Source: Own research.

A significant topical area within the conducted research were fears declared by those surveyed related to their child remaining outside. Richard Louv believes that "fear is the strongest force that keeps parents from providing the children with the freedom they themselves enjoyed when they were little. Fear is an emotion that separates the child from all advantages from contact with nature that are necessary for correct development". ${ }^{15}$ This question allowed the parents to select more than one answer. The two responses chosen most frequently are: Air purity/ smog - 56.3\% - the study was conducted in Silesia, an area with particularly high air contamination levels ${ }^{16}$ - fears related to the safety of the child, being accosted by third parties, etc. $-56.3 \%$. The next most popular responses are: child safety, fears related to dangerous ideas of children during play

${ }^{15}$ R. Louv, Ostanie dziecko lasu. Jak uchronić dzieci przed zespotem deficytu natury, Mamania, Grupa wydawnicza Relacja, Warszawa 2008, p. 155.

$16<$ https://airly.eu/pl> [19.08.2019]. 
- $21.9 \%$, with those surveyed also indicating lack of peers of the child, with whom they could play, in the closest vicinity; parents also exhibit fears related to diseases and those related to children not remaining outside frequently enough $-3.1 \%$, as well as the dislike of the child getting dirty $-3.1 \%$.

A further issue of importance for the conducted study was to check, how much time in total, in the opinion of parents, their children spend outside during activities organised at education facilities from Monday to Friday. The parents provided responses on the basis of their knowledge concerning the current schoolyear. The most frequent responses were: one hour $(28.1 \%)$ and no time at all $(28.1 \%)$, and then, in order: four hours and more (15.7\%), 30 minutes $(15.6 \%)$, two hours $(9,4 \%)$, three hours $(3.1 \%)$. The results are visualised in diagram no. 3 .

Diagram no. 3

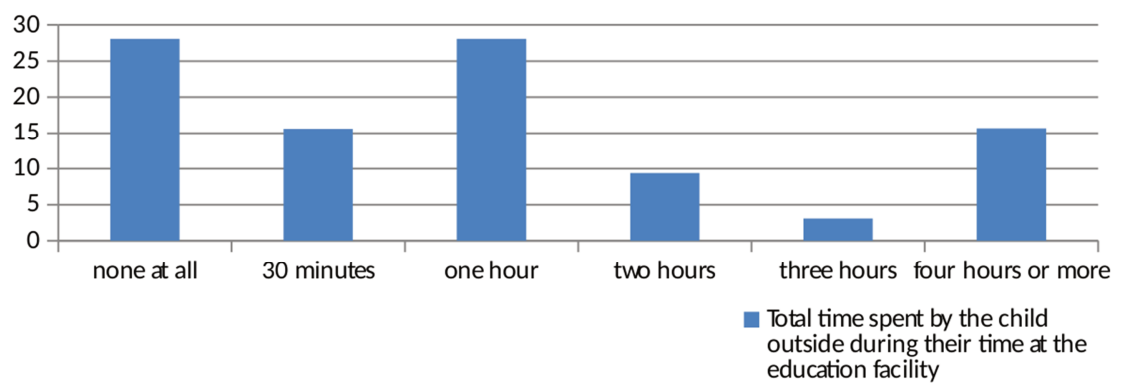

Source: Own research.

Then, a test was done how frequently in the month the respondents pick family activities outside (trips, walks, winter and summer sports, etc.). The results are presented in diagram no. 4 . The most frequent responses were: four times a month and more, picked by $50 \%$ of those surveyed; then follow: twice a month $-25 \%$ of responses; three times a month (15.6\% responses); $6.3 \%$ stated that they prefer other activities (visiting friends, the cinema, shopping), with just $3.1 \%$ of those surveyed organising trips once per month. 
Diagram no. 4

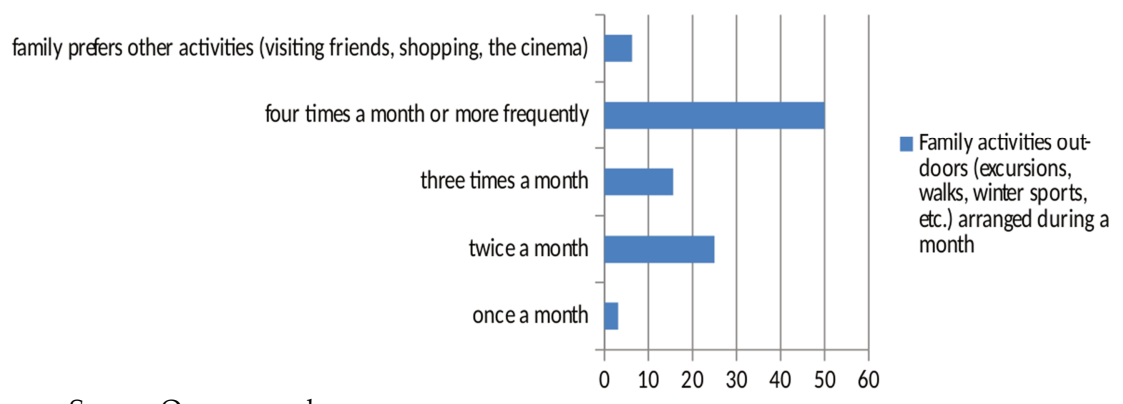

Source: Own research.

Diagram no. 5

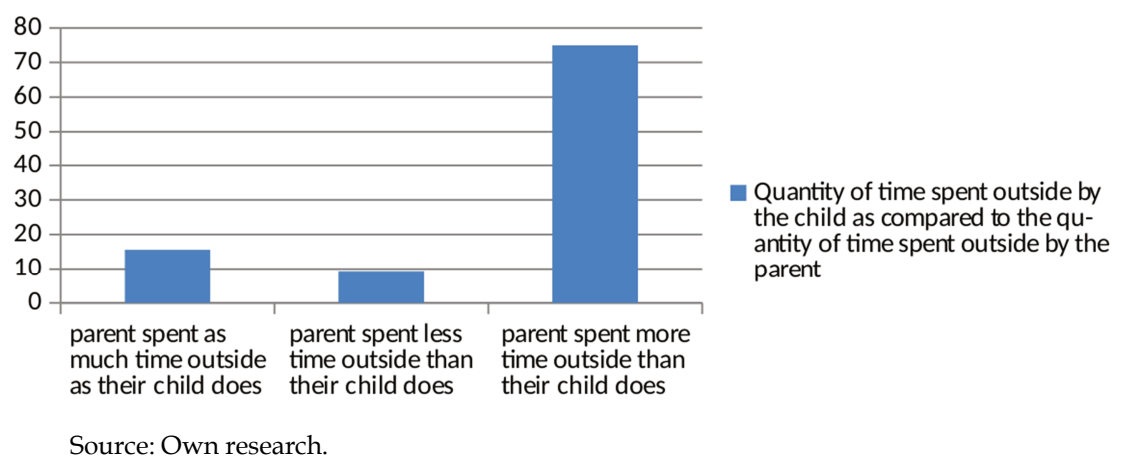

The study used reminiscences related to the childhood of the surveyed parents; they were asked about the relationship between the time spent by the parent during free play outside in their childhood and the time the child spends on independent, spontaneous play in the open. $75 \%$ of the surveyed parents stated that their child spends less time outside than they did when they were children; $15.6 \%$ of parents indicated that the child spends as much time outside as they did, and just $9.4 \%$ of the surveyed parents spent less time outside than their child does. The results are visualised in diagram no. 5, below. 
The parents were also asked to write a few sentences on their childhood in the context of spending time outside, in nature, playing with friends and acquaintances, doing sports outside, etc.

The most frequent answers are quoted below:

- We remained outside practically non stop,

- I spent a lot of time outside

- Those were the days...

- I spent time outside with my cousins. We spent time very actively, always playing ball, riding bicycles, swimming in the nearby river.

- This was the main form of spending free time. With friends, one could spend hours on end outside practically without any toys or equipment at one's disposal. It was great!

- I spent a lot of time outside; we had a house with a garden, right now I live in a block of flats.

- During childhood I spent a lot of time playing outside close to our home, my cousin and my siblings accompanied me frequently. We organised our playing ourselves.

- I spent a lot more time outside playing with my peers. We used to jump rope for hours, we played hopscotch, played with bottle tops. We used to run around the forest and the neighbourhood. We played on the carpet rack and hide-and-seek. There was no boredom!

- A lot of time with parents - playing, on walks; sleighing, ice-skating, playing in the snow together...

The surveyed parents were asked whether they feel to be guides in the world of nature for their child (e.g. they spend time together outside, discuss topics related to nature, organise excursions to the park, the forest, the river, watch flora and fauna, talk about the customs of animals, learn names and properties of plants, collect stones, shells, describe and explain observed natural phenomena, etc.), with respect to the concept of the mentor of nature as formulated by Scott D. Sampson. Mentors of nature, guides in the world of nature "listen actively and pose questions, encourage children to tell stories about their adventures with nature and listen in closely to them [...] they offer children their attention and reinforce the process of bonding 
with nature" ${ }^{17}$ The decisive majority $(63.7 \%)$ stated that they experience the world of nature together with the child, being their guide; $34.3 \%$ of those surveyed did not feel they were guides in the world of nature. The research results are visualised in diagram no. 6 .

Diagram no. 6

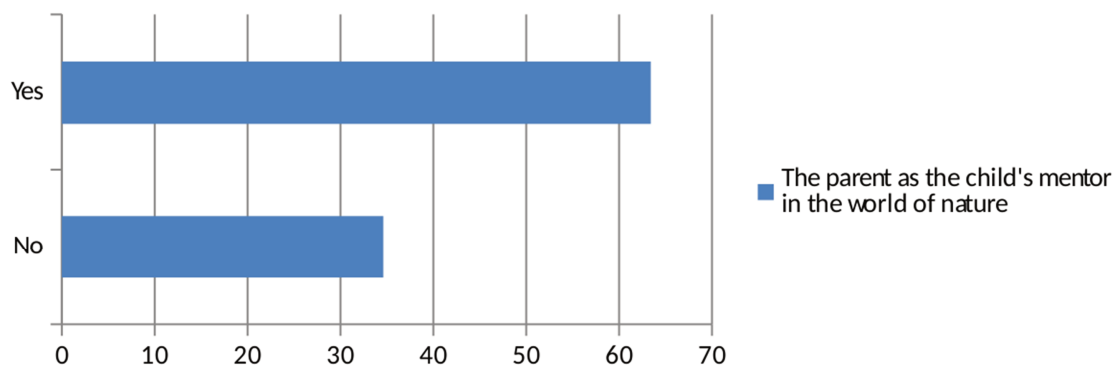

Source: Own research.

The surveyed parents were asked to write, how they spend time outside, surrounded by nature, with their family. ${ }^{18}$ The most frequent statements are indicated below:

- Walks in the forest, outings to the playground, trips to parks and other cities, trips to the zoo, barbecue on our recreational lot, playing in the garden, trips to rivers, lakes.

- Walks in the park, the children playing on the playground, cycling, short trips on foot, sometimes trips to the forest and in the weekendto the mountains. In winter, playing in the snow, sleighing if the weather allows this.

17 D. Scott Sampson, Kalosze petne kijanek. Jak dzięki rozwijaniu mitości do przyrody wychować kreatywne, odważne i odpowiedzialne dziecko, Wydawnictwo Vivante, Białystok 2016, p. 98.

${ }^{18}$ D. Scott Sampson, Kalosze petne kijanek. Jak dzięki rozwijaniu miłości do przyrody wychować kreatywne, odważne i odpowiedzialne dziecko, Wydawnictwo Vivante, Białystok 2016, p. 98. 
- Trips to the wild, work in the garden, skiing trips, cycling trips, rollerblading.

- I played often in the forest that directly adjoined grandma's house and in her home garden, together with cousins. Our house was part of a settlement, after school I always spent time outside with my friends; cycling, long walks across nearby fields.

- Work in the garden, skiing, downhill skiing, walks, walks in the forest, mushroom picking, mountain excursions.

- Walks in the forest, playing on the playground, planting in the garden, trips to the lake, playing badminton, cycling and rollerblading.

- Walks, the pool in the summer, frequent cycling.

\section{Summary and conclusions}

As the conducted research shows, the total time declared by parents that children spend outside on school days is mostly one hour $(31.3 \%)$ or two hours $(25 \%)$, so one can assume that there are days, when children do not venture outside at all or spend 15-30 minutes in the open daily. This is a topical area requiring further research, and results obtained up to now may be considered troubling in the context of the nature exclusion syndrome.

In the weekends, the children mostly spend three hours or more outside, as $65.6 \%$ of the surveyed parents stated; this would indicate that free time in the weekends is much more frequently related to outside activities.

Parental fears related to the child spending time outside are most commonly related to air quality and smog (56.3\%) and child safety, being accosted by unknown persons, etc. (56.3\%); what's interesting, $21.9 \%$ of the surveyed persons indicate child safety, fears related to safety, related to "strange/ dangerous" ideas that children get during play. "In our culture, we fear too much and are overly protective of children [...] whereas they are able to pick the level of risk suitable to their skills [...] in the process of development frustrations are also necessary, meaning, the experience of 
pain and failure". ${ }^{19}$ This is a further interesting field for further study from the perspective of parental attitudes with respect to time spent by children in nature.

The frequency of organisation of family activities outside per month is most commonly four times or more (50\% responses); just $6.3 \%$ of those surveyed preferred other activities (visiting acquaintances, the cinema, shopping), with just $3.1 \%$ of those surveyed organising trips once per month.

The results of the study on the relationship between the time spent by the parent in their childhood outside to the time the child presently spends outside playing, it was noted that even $75 \%$ of the analysed parents stated that their child spends less time outside than they did in their childhood; $15.6 \%$ of parents indicated that the child spends as much time outside as they did, and just $9.4 \%$ of those surveyed spent less time outside than their child does. These results show a disconcerting tendency towards a drastic reduction of the time the children spend outside.

The written statements made by parents on the time they spent outside during their childhood give rise to a certain notion of longing for this period of life, as well as the perception of changes in terms of generations, civilisation and culture, concerning the ever quicker pace of life and its general quality. ${ }^{20}$

The conducted study allows the conclusion that there exists a significant risk related to the deficit of contact with nature among Polish children; further research should be designed to encompass a much broader scale, testing not only parents and children with special education needs, to be followed by a comparative analysis.

${ }^{19}$ R. Kulik, Przyrodę trzeba mieć przede wszystkim utożona w sobie, [in:] $W$ dzika stronę. Rozmowy o edukacji w przyrodzie, Wydawnictwo Ośrodek Działań Ekologicznych "Źródła”, Łódź 2016, p. 50.

${ }^{20}$ After the survey, the parents frequently shared with the author their thoughts on the study, primarily related to the time their child spends among nature, saying that they were not aware of how little time their child spends playing outside as compared to the time when they were children; another reflection applied to independence and parental attitudes aiming towards their fullest possible protection. 
The phenomenon of contact of the child with nature should be analysed in a broader context, taking into account not only aspects related to free play outside, thanks to which a bond is established with the world of nature, but also getting to know the fauna and flora, getting to know and understand natural phenomena of animated and inanimate nature and issues of ecology. The concept of the mentor of nature must also be studied in more detail; their tasks and personal properties necessitate an analysis. A significant issue is checking the roles of teachers/ educators in terms of the natural and environmental awareness of children and their attitudes towards the world of nature.

Taking care of man's bond with nature counts among significant challenges of paedagogy and special paedagogy in the 21st century, because it does not occur only in the home, but also during classes at education facilities, where children should play, work and learn with as much contact with nature as possible - and where parents should learn good practices, patterns and inspirations to spend time with their children.

\section{Bibliography}

[1] Budniak A., Edukacja społeczno-przyrodnicza dzieci w wieku przedszkolnym i młodszym wieku szkolnym, Oficyna Wydawnicza „Impuls”, Kraków 2012, p. 162.

[2] Kulik R., Przyrodę trzeba mieć przede wszystkim ułożona w sobie, [in:] $W$ dzika stronę. Rozmowy o edukacji w przyrodzie, Wydawnictwo Ośrodek Działań Ekologicznych „Źródła”, Łódź 2016, p. 50.

[3] Macnaghten P., Urry J., Alternatywne Przyrody. Nowe myślenie o przyrodzie i spoteczeństwie, Wydawnictwo Naukowe SCHOLAR, Warszawa 2005, pp. 184-191.

[4] Meyer M., Pedagogika przeżywania, [in:] Adamczuk E. (ed.), Encyklopedia Pedagogiczna XXI wieku. T. 4, Wydawnictwo Akademickie „Żak”, Warszawa 2003, pp. 239-242.

[5] Louv R., Ostanie dziecko lasu. Jak uchronić dzieci przed zespotem deficytu natury, Mamania, Grupa wydawnicza Relacja, Warszawa 2008, pp. 148-155.

[6] Sampson D.S., Kalosze petne kijanek. Jak dzięki rozwijaniu mitości do przyrody wychować kreatywne, odważne i odpowiedzialne dziecko, Wydawnictwo Vivante, Białystok 2016, pp. 79-80. 
[7] Szadzińska E., Zrównoważony rozwój inspiracja dla zmian w edukacji wczesnoszkolnej, „Lubelski Rocznik Pedagogiczny” 2017, vol. XXXVI, issue 1, p. 30.

[8] W. Szymborska, The Silence of Plants, transl. by Joanna Trzeciak <https://www. poetrynook.com/poem/silence-plants>.

[9] Włodarczyk E., Kultura, [in:] Encyklopedia Pedagogiczna XXI wieku. vol. 2, G-Ł. ed. by E. Adamczuk, Wydawnictwo Akademickie "Żak", Warszawa 2003, p. 950.

[10] <https://airly.eu/pl> [19.08.2019].

[11] <http://stat.gov.pl> [19.08.2019].

[12] <http://unic.un.org.pl/strony-2011-2015/zrownowazony-rozwoj-i-cele-zrow nowazonego-rozwoju/2860> [30.05.2091]. 